\title{
Realized ecological niche of the Mexican Spotted Owl (Strix occidentalis lucida) in Mexico
}

\author{
Salazar-Borunda, M.A. ${ }^{1}$; Tarango-Arámbula, Luis Antonio ${ }^{2}$; López-Serrano, P.M. ${ }^{1}$; Chávez-Simental, J.A. ${ }^{1}$; \\ Olmos-Oropeza, Genaro ${ }^{2}$; Martínez-Guerrero, J.H. ${ }^{1}$; Pereda-Solís, M.E. ${ }^{{ }^{*}}$ \\ ${ }^{1}$ Universidad Juárez del Estado de Durango. Durango, Durango. México, C. P. 34000. \\ ${ }^{2}$ Colegio de Postgraduados Campus San Luis Potosí. Posgrado de Innovación en Manejo de Recursos \\ Naturales. Salinas de Hidalgo, San Luis Potosí. México, C. P. 78620. \\ *Corresponding author: mepereda@ujed.mx
}

\begin{abstract}
Objective: To characterize the realized niche of the Mexican spotted owl (Strix occidentalis lucida) and compare the environmental values it uses within the Mexican physiographic provinces.

Design/methodology/approach: The environmental temperature variables $(n=7)$, precipitation $(n=7)$ and elevation $(n=1)$ were extracted from 79 unique occurrences sites of $S$. o. lucida. These values were grouped by physiographic provinces: Sierra Madre Occidental $(n=59)$, Sierra Madre Oriental $(n=13)$ and Transverse Neovolcanic Belt $(n=6)$. The climate and elevation of these sites were described and compared via nonparametric Kruskal-Wallis and Bonferroni-Dunn tests ( $\mathrm{P} \leq 0.05)$.

Results: The presences of the spotted owls were both, dispersed and focally distributed, over the geographic space in Mexico. The temperature and elevation variables have similar characteristics in the assessed physiographic provinces. To be noted, the precipitation variables showed significant differences among sites.

Limitations on study/implications: This study describes the environmental characteristics of the realized niche of the Mexican spotted owl; however, it is necessary to investigate other habitat variables at a smaller scale.

Findings/conclusions: The temperature and elevation environmental characteristics of the ecological niche of the Mexican spotted owl was similar between physiographic provinces.
\end{abstract}

Keywords: Realized niche, climate, elevation, Mexican Spotted Owl.

Citation: Salazar-Borunda, M.A., Tarango-Arámbula, Luis Antonio, López-Serrano, P.M., Chávez-Simental, J.A., OlmosOropeza, Genaro, Martínez-Guerrero, J.H., \& Pereda-Solís, M.E. (2021). Realized ecological niche of the Mexican spotted owl (Strix occidentalis lucida) in Mexico. Agro Productividad, 14(\#). https://doi. org/10.32854/agrop.v14i6.2020

Editor in Chief: Dr. Jorge Cadena Iñiguez

Estimated publication date: July 2021

This work is licensed under a Creative Commons Attribution-NonCommercial 4.0 International license cc) $\$$

\section{INTRODUCTION}

Resource availability and environmental conditions vary across a species range (Gaston, 2009), with differences especially marked in widely distributed species (Brown et al., 1996). Under Hutchinson's (1957) concept, these differences can be observed by contrasting realized niche characteristics $\left(\mathrm{N}_{\mathrm{R}}\right)$.

The $N_{R}$ is defined as the set of biotic and abiotic factors that allow a specie's presence (Vázquez, 2005). In this sense, studies investigating it are scarce and focus on occupancy predictive models (fundamental ecological niche) derived from climatic, vegetation and elevation variables (Palma-Cancino et al., 2020), in large regions at spatial resolutions of approximately $1 \mathrm{~km}^{2}$ (Sutton et al., 2020). This misinformation is accentuated in poorly observed species (Pearce and Boyce, 2006) which in turn, limits the available information to establish management and conservation measures for these species (SEMARNAT, 2010; USFWS, 2012).

The $N_{R}$ characteristics are not clear in elusive birds with wide and discontinuous distributions such as the Mexican Spotted Owl (MSO; Strix occidentalis lucida). The MSO 
inhabits forests, from the southwestern United States to the physiographic provinces: Mexican Sierra Madre Occidental (SMO) Sierra Madre Oriental (SMOR), and the Transverse Neovolcanic Belt (TNB) (USFWS, 2012). This subspecies is listed in Mexico as threatened (SEMARNAT, 2010) and globally as near threatened (BirdLife International, 2020).

For the MSO, forest loss and fragmentation have been the main threats to its populations (Wan et al., 2018), which has led to their habitats being the most studied ecological attribute of this raptor (Salazar-Borunda et al., 2020).

Despite substantial evidence suggesting the wide range of environments used by MSO (Bowden et al., 2015; Hoagland et al., 2018; Silva-Piña et al., 2018), studies explicitly quantifying and comparing the $\mathrm{N}_{\mathrm{R}}$ between geographically distant populations are not available. Considering that the description of the environmental characteristics of the sites where this bird inhabit will enrich the available information to those responsible for their management and conservation, the objectives of this work were: i) to characterize the $\mathrm{N}_{\mathrm{R}}$ of MSO in Mexico and ii) to compare their used environmental variables between Mexican physiographic provinces.

\section{MATERIALS AND METHODS}

\section{Study area}

The study area was defined as the range of the MSO distribution area in Mexico and included the physiographic provinces of importance for their conservation: Sierra Madre Occidental (SMO), Sierra Madre Oriental (SMOR) and the Transverse Neovolcanic Belt (TNB) (USFWS, 2012). This constitutes a continental surface of $733131 \mathrm{~km}^{2}$ and contains diverse climatic groups (De Alba and Reyes, 1998).

\section{Occurrence data}

The presences of MSO perch sites in Mexico were obtained from the Global Biodiversity Information Facility platform (GBIF, 2019; 83 points) and field observations collected between 2018 and 2020 (25 points). Repeated coordinates and with georeferencing error were removed from the database, using spThin (Aiello-Lammens et al., 2015) and remove.duplicates (Pebesma and Bivand, 2005) in the R statistical software (version 4.0.5, R Core Team, 2021).

\section{Environmental characteristics}

Climate and elevation variables were obtained from WorldClim (version 2.1, Fick and Hijmans, 2017) at 30 arc-seconds $\left(\sim 1 \mathrm{~km}^{2}\right)$ of spatial resolution. The climate data represent the annual patterns of temperature (mean annual, maximum of the warmest month, minimum of the coldest month, the mean temperature of the wettest, driest, warmest, and coldest quarters) and precipitation (annual and of the wettest, driest, warmest, and coldest months). 


\section{Characterization of the ecological niche}

The environmental (climatic and elevation) and presence variables were projected to the geographic space in QGIS (version 3.4.15, QGIS, 2018). To extract the environmental values for each presence point, the Point Sampling Tool add-on was used. These values were grouped by province into three groups: a) SMO, b) SMOR and c) TNB.

\section{Statistical analysis}

Descriptive and dispersion statistics were calculated for the environmental variables. All statistical analyses were performed in the $\mathrm{R}$ statistical software (version 4.0.5, R Core Team, 2021) with an $\alpha=0.05$ significance level. In this phase, the normality of the data series was tested with the Kolmogorov-Smirnov test and the homogeneity of variance with the Levene test. To compare the environmental variables between groups, the Kruskal-Wallis and Bonferroni-Dunn nonparametric tests were used.

\section{RESULTS AND DISCUSSION}

\section{Occurrence data}

Seventy-nine records of the MSO presence were obtained (Figure 1).

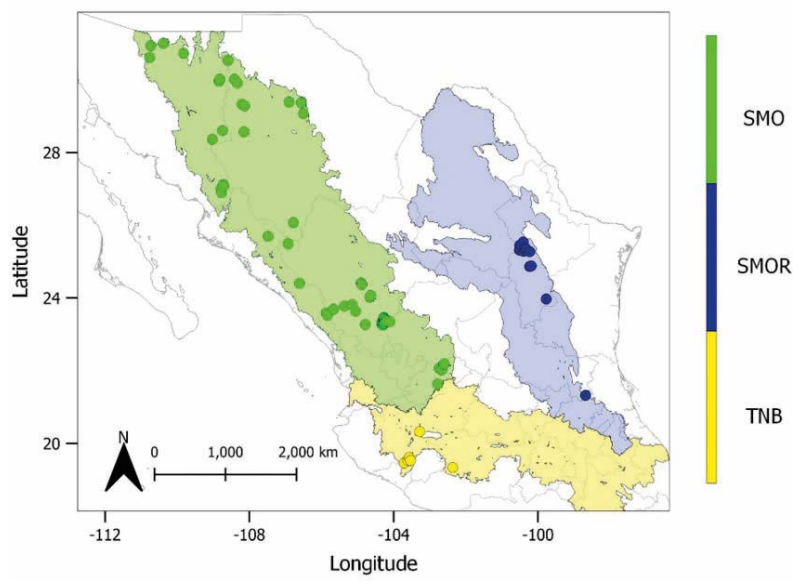

Figure 1. Occurrences of the Mexican spotted owl (points) in the Sierra Madre Occidental (SMO), Sierra Madre Oriental (SMOR) and Transverse Neovolcanic Belt (TNB) provinces.

The physiographic province with the most spotted owl records in Mexico was the SMO $(\mathrm{n}=59)$, followed by the SMOR $(\mathrm{n}=13)$ and TNB $(\mathrm{n}=6)$. It appears that the observations are distributed in a dispersed manner over the geographic space of the province with the most records and in a focal manner in the other two (in which there are probably poorly explored areas).

\section{Realized ecological niche $\left(\mathbf{N}_{\mathbf{R}}\right)$}

The $\mathrm{N}_{\mathrm{R}}$ of $\mathrm{MSO}$ was characterized from environmental variables derived from temperature $(n=7)$, precipitation $(n=7)$ and elevation $(n=1)$ in the physiographic provinces of importance in owl conservation (Table 1 ). 
Table 1. Environmental ranges used by Strix occidentalis lucida in Mexico. All temperature variables are expressed in ${ }^{\circ} \mathrm{C}$, precipitation in $\mathrm{mm}$ and elevation in masl.

\begin{tabular}{l|c|c|c}
\multirow{2}{*}{\multicolumn{1}{c}{ Environmental variables }} & \multicolumn{3}{c}{ Physiographic provinces } \\
\cline { 2 - 4 } & SMO & SMOR & TNB \\
\hline Annual mean temperature & $10.50-24.11$ & $10.35-24.00$ & $10.45-20.78$ \\
\hline Maximum temperature of warmest month* & $23.00-38.90^{\mathrm{ac}}$ & $20.00-34.10^{\mathrm{b}}$ & $19.20-31.30^{\mathrm{ab}}$ \\
\hline Minimum temperature of the coldest month** & $-4.9-12.10^{\mathrm{bc}}$ & $0.6-12.3^{\mathrm{ab}}$ & $1.0-8.4^{\mathrm{ac}}$ \\
\hline Mean temperature of wettest quarter & $14.15-28.15$ & $12.21-16.80$ & $11.85-22.45$ \\
\hline Mean temperature of driest quarter & $8.0-24.27$ & $7.90-19.08$ & $9.75-19.51$ \\
\hline Mean temperature of warmest quarter & $15.06-29.31$ & $12.64-27.60$ & $12.30-22.81$ \\
\hline Mean temperature of coldest quarter** & $3.81-20.21^{\mathrm{a}}$ & $7.43-19.08$ & $7.96-18.00$ \\
\hline Annual Precipitation** & $406-1247^{\mathrm{a}}$ & $462-1805^{\mathrm{b}}$ & $924-1342^{\mathrm{c}}$ \\
\hline Precipitation of wettest month ** & $101-289^{\mathrm{a}}$ & $75-335^{\mathrm{b}}$ & $207-282^{\mathrm{c}}$ \\
\hline Precipitation of driest month** & $2-15^{\mathrm{a}}$ & $12-49^{\mathrm{bc}}$ & $1-10^{\mathrm{ac}}$ \\
\hline Precipitation of wettest quarter** & $271-763^{\mathrm{a}}$ & $206-764^{\mathrm{b}}$ & $556-774^{\mathrm{c}}$ \\
\hline Precipitation of driest quarter** & $11-55^{\mathrm{a}}$ & $45-152^{\mathrm{b}}$ & $12-38^{\mathrm{c}}$ \\
\hline Precipitation of warmest quarter** & $206-673^{\mathrm{a}}$ & $169-681^{\mathrm{b}}$ & $403-542^{\mathrm{a}}$ \\
\hline Precipitation of coldest quarter & $24-185$ & $47-152$ & $24-85$ \\
\hline Elevation & $353-2835$ & $270-3555$ & $1255-3300$ \\
\hline
\end{tabular}

Environmental variables (minimum value - maximum value) of the ecological niche of the Mexican Spotted Owl in the Mexican physiographic provinces: Sierra Madre Occidental (SMO), Sierra Madre Oriental (SMOR) and Transverse Neovolcanic Belt (TNB). ${ }^{*} \mathrm{P} \leq 0.01 ;{ }^{*} \mathrm{P} \leq 0.05$ (Kruskal-Wallis). Different literals indicate significant differences between sites (Bonferroni-Dunn, $\mathrm{P}<0.05)$.

The results suggest that MSO distributes in diverse environments. Some $\mathrm{N}_{\mathrm{R}}$ variables are different among provinces (Figure 2); apparently, temperature extremes in short periods (maximums at the hottest and coldest months) and precipitation variables are characteristics that differ among realized niches.

Precipitation has been positively associated with the availability of trophic resources and, in turn, with the reproductive efficiency and survival of this raptor (Seamans et al., 2002). In this study, the precipitation variables differed among sites, reflecting that the Mexican spotted owl may be more tolerant to this variable's fluctuation.

On other hand, the mean annual temperature and elevation are characteristics in common among $\mathrm{N}_{\mathrm{R}}$ and probably determinant for site occupancy by the MSO. In this sense, the predictive importance of the temperature and elevation variables on this subspecies potential distribution was reported by Palma-Cancino et al. (2020), these, in turn, are associated with the MSO's thermoregulatory mechanisms (Ganey, 2004). Although the average elevation (2160 masl) of the sites coincides with the rugged topography described for the subspecies (Tarango et al., 1997; Tarango et al., 2001; May et al., 2004), it seems that this owl is distributed in areas with a lower altitude than the reported minimum (2072 masl; Young et al., 1997).

This research demonstrates that $\mathrm{N}_{\mathrm{R}}$ analysis is an important tool to understand the environmental conditions in which widely distributed birds of prey inhabit and, at the 
same time, strengthen the knowledge of sensitive and understudied species. Therefore, this research provides a framework to explore other variables of the environment occupied by the MSO, i.e., the description of the biotic and abiotic interactions and their impact on the population dynamics of the subspecies.
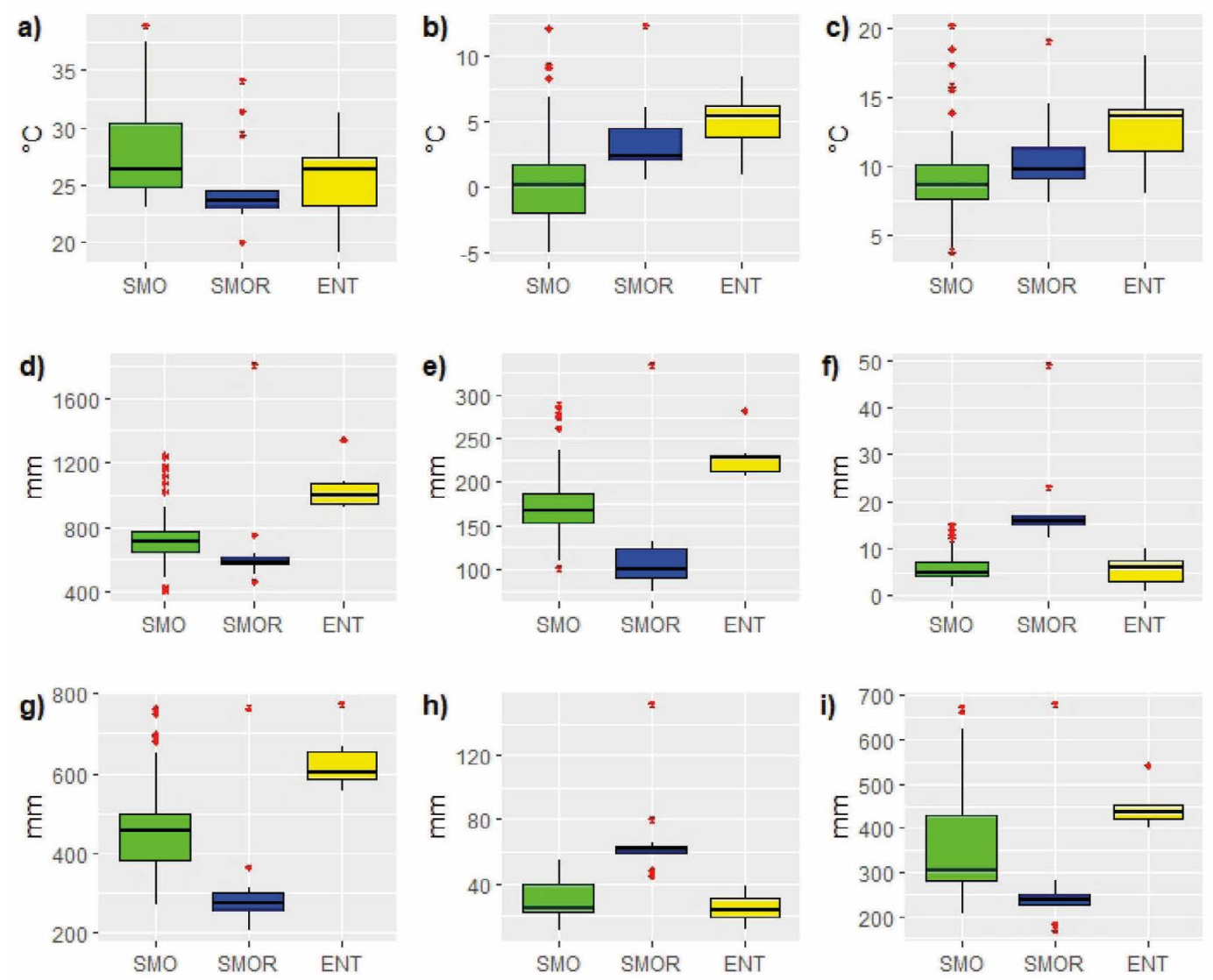

Figure 2. Environmental variables of Mexican Spotted Owl occurrences in the phisiographic provinces: Sierra Madre Occidental (SMO), Sierra Madre Oriental (SMOR) and Transverse Neovolcanic Belt (TNB). Variables derived from temperature $\left({ }^{\circ} \mathrm{C}\right)$ : a) maximum of the warmest month, b) of the coldest month, c) mean of the coldest quarter, and variables derived from precipitation $(\mathrm{mm}) \mathrm{d}$ ) annual e) mean of the wettest month, f) driest month, g) the wettest quarter, h) driest and i) warmest quarter.

\section{CONCLUSIONS}

The climatic and elevational characteristics of the $\mathrm{N}_{\mathrm{R}}$ of the Mexican spotted owl (Strix occidentalis lucida) in Mexico were described. The Mexican physiographic provinces of importance for the conservation of this raptor have similar temperature and elevation ranges. However, the relation between this bird's presence and the environment is undoubtedly more complex. The generated data provide a general description of the thermal, elevational and precipitation regimes of this subspecies. They also provide a framework for exploring other $\mathrm{N}_{\mathrm{R}}$ variables of this subspecies at a smaller scale. 


\section{ACKNOWLEDGMENTS}

We thank the Consejo Nacional de Ciencia y Tecnología, the Universidad Juárez del Estado de Durango, specifically to Juan Felipe Martínez Montoya, Marcelo Márquez Olivas, Davira Yolanda Palma Cancino, Javier Rafael Valdez and Mariana Jovita Silva-Piña, for the information on the presence of the Mexican Spotted Owl. Idem to the reviewers whose comments enriched this manuscript.

\section{REFERENCES}

Aiello-Lammens, M.E., Boria, R.A., Radosavljevic, A., Vilela B., \& Anderson, R.P. (2015). spThin: An R package for spatial thinning of species occurrence records for use in ecological niche models. Ecography 38(5): 541-545. doi: https://doi.org/10.1111/ ecog.01132

Birdlife International (2020). Strix occidentalis. The IUCN Red List of Threatened Species 2020: e.T22689089A180937862. doi: https://dx.doi.org/10.2305/IUCN.UK.2020-3.RLTS.T22689089A180937862

Bowden, T.S., Ferguson, J.M., Ward, R.V., Taper, M.L. \& Willey D., W. (2015). Breeding season home range and habitat use of mexican spotted owls (Strix occidentalis lucida) below the south rim of Grand Canyon National Park. The Wilson Journal of Ornithology 127(4):678-689, doi: https://doi.org/10.1676/15-004.1

Brown, J.H., Stevens, G.C.A., \& Kaufman, D.M. (1996). The Geographic Range: Size, shape, boundaries, and internal structure. Annual Review of Ecology and Systematics 27: 597-623. doi: https://doi.org/10.1146/annurev ecolsys.27.1.597

De Alba, E., y M.E. Reyes. (1998). Contexto físico: La diversidad biológica de México estudio de país. Ciudad de México: Comisión Nacional para el Conocimiento y Uso de la Biodiversidad.

Fick, S.E., \& Hijmans, R.J. (2017). WorldClim 2: new $1 \mathrm{~km}$ spatial resolution climate surfaces for global land areas. International Journal of Climatology 37 (12): 4302-4315. doi: https://doi.org/10.1002/joc.5086

Ganey, J.L. (2004). Thermal regimes of Mexican spotted owl nest stands. The Southwestern Naturalist 49(4): 478-486. doi: 10.1894/0038-4909(2004)049<0478:TROMSO>2.0.CO;2

Gaston, K. J. (2009). Geographic range limits of species. Proceedings of the Royal Society B: Biological Sciences 276: 1391. doi: https:// doi.org/10.1098/rspb.2009.0100.

Hoagland. S.J., Beier, P., \& Lee, D. (2018). Using MODIS NDVI phenoclasses and phenocluster to characterize wildlife habitat: Mexican spotted owl as a case study. Forest Ecology and Management 412(15): 80-93, doi: https://doi.org/10.1016/j. foreco.2017.12.017.

Hutchinson, G.E. (1957). Concluding remarks. Cold Spring Harbour Symposiumon Quantitative Biology, 22: 415-427. doi: https://doi. org/10.1101/SQB.1957.022.01.039.

May, C.A., Petersburg, M. L., \& Gutiérrez, R. J. (2004). Mexican spotted owl nest-and roost-site habitat in northern Arizona. The Journal of wildlife management, 68(4): 1054-1064. doi: https://doi.org/10.2193/0022-541X(2004)068[1054:MSONAR]2.0.CO;2.

Palma-Cancino, D.Y., Tarango-Arámbula, L.A., Ugalde-Ledezma, S., Alcántara-Carbajal, J.L., Olmos-Oropeza, G., Ángeles-Pérez, G., \& Rincón-Ramírez, J.A. (2020). Distribución potencial del tecolote moteado mexicano (Strix occidentalis lucida Nelson 1903) en Aguascalientes, Durango, Jalisco y Zacatecas México. AgroProductividad 12(1): 23-28. doi: https://doi.org/10.32854/ agrop.vi0.1563

Pearce, J.L., \& Boyce, M. S. (2006). Modelling distribution and abundance with presence-only data. Journal of Applied Ecology 43: 405-412. doi: https://doi.org/10.1111/j.1365-2664.2005.01112.x

Pebesma, E. J., \& Bivand, R.S. (2005). Classes and methods for spatial data in R. (1.a ed., Vol. 5). R News.

QGIS (3.4.15). (2018). [Software]. QGIS Development Team. http://qgis.org.

Salazar-Borunda, M.A., Martínez-Guerrero, J.H., Tarango-Arámbula, L.A., Pereda-Solís, M.E., y López-Serrano, P.M. (2020). Avances científicos del búho manchado mexicano (Strix occidentalis lucida Nelson 1903). AgroProductividad 13(6):43-48. doi: https:// doi.org/10.32854/agrop.vi.1681 
Seamans, M.E., Gutiérrez, R.J., \& May, C.A. (2002). Mexican Spotted Owl (Strix occidentalis) population dynamics: Influence of climatic variation on survival and reproduction. The Auk 119(2): 321-334. doi: https://doi.org/10.1093/auk/119.2.321.

Silva-Piña, M.J., Tarango-Arámbula, L.A., Clemente-Sánchez, F., Cortéz-Romero, C., Velázquez-Martínez, A., Valdez, R., y UgaldeLezama, S. (2018). Características del hábitat de sitios de descanso del búho manchado (Strix occidentalis lucida) en la Sierra Madre Occidental, México. Huitzil 19(2): 141-156, doi: https://doi.org/10.28947/hrmo.2018.19.2.319

Sutton, L.J., McClure, C.J., Kini, S., \& Leonardi, G. (2020). Climatic Constraints on Laggar Falcon (Falco jugger) Distribution Predicts Multidirectional Range Movements under Future Climate Change Scenarios. Journal of Raptor Research 54(1): 1-17. doi: https:// doi.org/10.3356/0892-1016-54.1.1

Tarango, A.L.A., Valdez, R., Clemente, F., \& Mendoza, G. (2001). Roost-site characteristics of Mexican spotted owls in Sierra Fria, Aguascalientes, Mexico. Journal of Raptor Research 35: 165-168.

Tarango, A.L.A., Valdez, R., Zwank, P.J., \& Cardenas, M. (1997). Mexican spotted owl habitat characteristics in Southwestern Chihuahua, México. The Southwestern Naturalist 42(2): 132-136. doi: https://www.jstor.org/stable/30055252

United States Fish and Wildlife Service (USFWS). (2012). Final Recovery Plan of the Mexican spotted owl (Strix occidentalis lucida), First Revision. U. S. Fish and Wildlife Service. Albuquerque, New Mexico. USA. 413 pp.

Vázquez, D.P. (2005). Reconsiderando el nicho hutchinsoniano. Ecología austral, 15(2): 149-158. http://ojs.ecologiaaustral.com. ar/index.php/Ecologia_Austral/article/view/1462

Wan, H.Y., Ganey, J.I., Vojta, C.D., \& Cushman, S.A. (2018). Managing emerging threats to spotted owls. The Journal of Wildlife Management 82(4): 682-697. doi: https://doi.org/10.1002/jwmg.21423

Young, K.E., Zwank, P.J., Valdez, R., Dye, J.L., \& Tarango, L.A. (1997). Journal of Raptor Research 31 (4): 376-380. https://www.fs.fed. us/psw/publications/4251/young.pdf 